\title{
Comparison of Engineering Education in Norway and China
}

\author{
Xiaodong Sun ${ }^{1,2}$, Yanrui Jia ${ }^{1}$, Zhenchun $\operatorname{Li}^{1} \&$ Yu Song ${ }^{1}$ \\ ${ }^{1}$ School of Geosciences, China University of Petroleum (East China), Qingdao, China. \\ ${ }^{2}$ Laboratory for Marine Mineral Resource, Qingdao National Laboratory for Marine Science and Technology, \\ Qingdao, China. \\ Correspondence: Xiaodong Sun, School of Geosciences, Qingdao, China University of Petroleum (East China), \\ China.
}

Received: December 10, 2017

Accepted: January 25, $2018 \quad$ Online Published: January 27, 2018

doi:10.5430/ijhe.v7n1p98

URL: https://doi.org/10.5430/ijhe.v7n1p98

\begin{abstract}
The Washington Accord is an internationally recognized agreement in engineering education of undergraduates. China joined the agreement as the 18th member country in 2016. The exploration technology and engineering major of China University of Petroleum has obtained the professional certification from international engineering education system and will adopt the international standards of personnel training that is substantially equivalent to the Washington Accord to train students. Based on the personal experience of two years of study abroad combining with the major, the author compares the difference of engineering education at home and abroad. At the same time, according to the domestic actual situation of education and the overall situation of students, the author gives corresponding opinions and improvement methods.
\end{abstract}

Keywords: Washington Accord, Engineering education, International standard

\section{Introduction}

The Washington Accord is an international mutual recognition agreement for undergraduate engineering education. Founded in 1989 by engineering specialists in the United States, Britain and other countries, the Washington Accord aims to ensure the quality of engineering education through undergraduate professional certification in engineering education (Walter \& Wu, 2017). On June 2, 2016, the Assembly of International Engineering Consortium passed the application by China. Therefore, China became the $18^{\text {th }}$ formal member of Washington Accord (Lin, 2016). This indicates that the quality of engineering education in our country is internationally recognized and the internationalization of engineering education has taken an important step.

Engineering education in China achieves international mutual recognition which brings opportunities to major of exploration technology and engineering in our school (Kong, Ye \& Wang, 2013). Joining the Washington Accord is an important measure to promote Chinese engineers training in accordance with international standards and improve the quality of engineering and technical personnel training. It is the basis and key to promoting international mutual recognition of engineers (Zhu, 2011). It is of great significance for China's engineering and technology fields to cope with international competition and to go to the world. China's engineering education will adopt an international standard of personnel training that is substantively equivalent to the Washington Accord (Zhang, Kong \& Chen, 2012). China's professional engineering education system and accreditation results will be accredited by the countries and regions that have signed the Washington Accord. Students go to the world with pass of international quality standards, which laid the foundation for the implementation of the system of professional engineers in our country (Chen, Ye \& Mei, 2013).

Since graduates who pass the professional engineering education will obtain the qualification of internationally licensed engineers, the students obtain the diploma issued by universities, which is equivalent to obtaining the pass for employment in the international market (Han, Yan \& Wang, 2015). The engineering education certifications all over the country have been widely promoted by major universities, especially well-known colleges and universities.

\section{Problems and Solutions}

Comparing with the engineering education in relevant international universities, we still need to make great efforts to improve and develop (Zhu, 2015). The authors have spent one year as visiting scholar and visiting researcher at the Norwegian University of Science and Technology. During the visit, the author joined the research group led by 
professors and conducted joint research and academic exchange in the field of exploration technology and engineering (Zhou, Zhu \& Li, 2016). In addition, during spare time, the author listened to most major undergraduate and graduate courses. NTNU is the far best university in Norway which stands for the highest quality of Norwegian education. By the way, there is author's major in this university. According to graduation requirements of professional engineering certification, combined with the characteristics of this major, there are some profound personal experiences on advanced engineering education concepts and methods in Norway.

\subsection{In order to Ensure Graduates' Core Competitiveness and Long-term Development, Basic Professional Education must not be Weakened}

Graduation requires students to apply mathematics, physics, chemistry, metrology, geology and expertise to solve complex engineering problems in exploration technology and engineering (Han \& Zheng, 2015). This requires us not only to strengthen the teaching of basic professional knowledge, but also pay attention to the cultivation of practical ability to operate. This is why international universities have a lot of homework. Basically they arrange an experiment every one or two weeks, so in each semester students have to do nearly ten experiments. Such experiments are often difficult to do, not as easy as performing a general survey of the literature to write a report. The experiments need to be done manually via programing on computer, doing various tests in the laboratory, demanding theoretical knowledge and practical ability. This is why international college students in the classroom concentrate their attention and like to ask questions. Because if they do not understand in class, it will be very difficult to do the experimental work after class. In order to complete the experimental homework, students usually stay up late and study overtime even during weekend. These lab assignments plus the weekly exams are counted towards the final exam score. In such an environment of high intensity and strict requirements, it has been very difficult for most students to take on three or four courses per semester and pass final examinations (Li \& Xiang, 2016). Students who can finally get credit for one course must have mastered the necessary knowledge and necessary skills of the course.

However, the practical problems have come. Teachers often have heavy scientific research tasks. How can there be so much time for answering dozens or even hundreds of students and counseling experiments? The solution is to recruit more senior students who have taken the course and achieved good grades as teacher assistants, answering questions and counseling. Student assistants can get paid from their work.

Assignments, experimental homework and weekly exams are taken in account for the final results of a course which guarantee the quality of teaching and learning. In addition, hiring TA also ensures that students can be given timely counseling (Zhu, 2016). In contrast, some domestic science and engineering courses examinations have tendency of ease, that is, to reduce the difficulty of the exam to more discussion, short answer and other text-based questions. Students usually do not have to spend too much effort in daily study but just memorize some knowledge without understanding before the exam to get high scores. The author made contrast between the Russian students who study abroad in master's degree programs with those who have studied in China. It turned out that Russian students generally have more mathematical knowledge and professional basic knowledge, which reflects the high education quality of their university.

\subsection{Practical Training Session and in-class Teaching are Equally Important, Playing Compulsory Part of Engineering Education}

Graduation requires the ability to design solutions to complex engineering problems in exploration geophysics, program designing capabilities to explore geophysical field acquisition, data processing, and geologic interpretation, as well as make innovation of design considering social, healthy, safe, legal, cultural and environmental factors. This requires us to strengthen the quality control of students' internship during the process so that students can actually get trained substantially rather than acting as audience. International universities and institutes attach great importance to the internship for students. Before the summer vacation, there will be a large number of companies that release internship positions (Gao, Yang \& Wen, 2014). Students' internship performance is not only an important indicator of students' academic performance but also an important reference for recruiting students. With no doubt students will cherish the opportunity during the internship and do their best. Norwegian University of Science and Technology is located very closely to SINTEF research institute which is the largest one in Scandinavian Peninsula and Statoil which is the largest state owned oil company in Norway. So students have plenty of internship opportunities in industry and acquire competence for their future career development. In contrast, for the professional engineering education in some universities in China, internship is not emphasized enough. Students also take it as a relaxing thing. Of course, the deeper reason is that the students' basic knowledge is not solid enough, and their attitude towards internship is not taken seriously. As a result, they have neither the adequate ability nor the intention to participate in specific work in the internship program. Therefore, some companies in petroleum industry are not 
enthusiastic about cultivating students and providing internship positions. Therefore, we should increase the proportion of credits in student internship when evaluating their performances and ensure the quality of our engineering education. In addition, some policies should be made to stimulate companies in China to provide more opportunities in internship and make sure students are willing to participate in internship at their best.

\subsection{Strengthen Bilingual and English Teaching, Training of International Engineers}

Graduation requires students to have a certain international perspective, be able to read and understand foreign scientific and technological literature, fluent use of foreign languages to communicate and exchange $(\mathrm{Li}, \mathrm{Xu} \& \mathrm{Chen}$, 2012).

Usually after one lecturer is finished, some foreign students from Africa gather around the teacher for a long time communications without any language barriers. In contrast, most Chinese students, though having a stronger mathematical basis and professional knowledge, are too conservative to speak publicly. Not being able to communicate well, they prefer to spend most of their time silently as audiences. For current undergraduate engineering education programs, we only provide students with a course in professional foreign languages during the fourth year of college study to equip students with some basic professional vocabulary, professional literature reading and essay writing knowledge. Apparently this is not enough even if we got the professional certification with international quality standards. Due to their limited ability in English, they could hardly compete in the international job market or apply for further study opportunities. The author suggests that with the precondition of guaranteeing the quality of education, the university curriculum should include bilingual or even English teaching as much as possible so as to enhance the students' international competitiveness in the future. Obviously, developing internationalized talents poses higher requirements for teachers as well as corresponding incentives to ensure that teachers are willing to spend more time and energy on bilingual and English teaching.

\subsection{Train Students to Acquire the Ability of Communication and Collaboration}

According to the international standard of engineering education, it requires students to have a certain degree of management skills through training, have a strong sense of teamwork and collaboration, and be able to take the roles of individual, team member or principal in a multidisciplinary team (Zeng, Shen \& Tao, 2013). Students are needed to communicate and exchange views effectively with industry peers and the general public on the implementation of exploration geophysical issues including field conduction and indoor interpretation, including writing reports and designing drafts, making presentations, articulating or responding to directives, and having certain international insights, can communicate and exchange under the cross-cultural background.

In Norway, group homework is assigned during a semester. It requires a group of 3 to 5 students to solve a problem in collaboration. In some organized seminars, student groups are required to give oral or poster presentations in order to get credits from teachers. In our daily teaching activity, students are required to submit written homework which should be finished individually and independently. This kind of assessment has both advantages and disadvantages. The positive aspect is to monitor the individual knowledge and skill for each student. On the other hand, the negative aspect is lack of training on students' teamwork and communication skills. The reason why such written assignments and written exams are taken is still limited by the lack of a teaching assistant system. That is because assigning credit to individual by judging written homework and exam is more efficient and saves a lot of time. Another one is that how to evaluate student's individual contribution in teamwork and assign fair credits for each member in a group remains a problem.

Now the situation is that students do not have strong communication skills and spirit of collaboration, so teachers do not want to arrange such teamwork. Thus following such circle, the fact results that most students are not good at reporting, speaking in public, lacking coordination and management ability (Xie, 2016). The lack of these skills will seriously affect the future career development of students after graduation (Yu, 2013). What we need to change is to increase the oral test credit of the students besides written assignments and written tests, to increase the teamwork and experiments. These are included in the student's grade assessment and evaluation system.

2.5 Increase Engineering Management and Economic Decision-making Knowledge and Skills to Promote Future Career Development of Engineers

For graduation, it requires students to understand and master the general knowledge of project management and economic decision-making. In the implementation of multidisciplinary projects, the project management principles and economic decision-making methods can be integrated, with the ability to run and manage projects (Peng, Lu \& Zhou, 2014). This requires us to provide training on professional knowledge and professional skills, as well as teaching related engineering management and technical economics knowledge. The students are needed not only to 
understand the professional knowledge, but also know how to implement the project management, economic decision-making. The interdisciplinary talents are more welcome by industry and their career development prospects will be better. However, the current status of education is that most of our students only care about the study of their own major unless they have double degrees. They have little or no curiosity about knowledge other than their majors (Han \& Zheng, 2015). Therefore, they lack basic engineering management and economic decision-making knowledge and skills which will affect the promotion of personal career in future. According to this requirement, we need to focus on a broader level of education and training for students to broaden their horizons.

\section{Conclusion}

International Mutual Recognition of Qualifications of Engineering education provides opportunity for students to get equivalent certificate and get recognized as qualified engineers worldwide as long as they graduate. However, it does not mean that the students already have the same competence as graduates from other countries in the international talent market. Therefore, we have made a lot of achievements in engineering education, but we still need to continuously improve our education quality in an international perspective. There is a bright future and a long way to go for universities in China and opportunities and challenges coexist ahead.

\section{Acknowledgements}

The authors are very grateful to Prof. Alexey for his cooperation during the visit to the Norwegian University of Science and Technology. Thanks are also given to all colleagues and students in the department of petroleum engineering and applied geophysics for survey and discussion. Thanks for the help from other colleagues and students in the Department of Geophysics, China University of Petroleum (East China). Last but not least, thanks for the feedback and suggestions from CNOOC Research Institute in China and SINTEF Research Institute in Norway.

\section{References}

Chen, J., Ye, Y., Mei, L. (2013). A new exploration of general education - engineering education. Higher Engineering Education Research, 31(3), 71-75.

Gao, C.H., Yang, X.X., Wen, B.Y. (2014). Research and Practice on Cultivating High-quality Engineering and Technological Talents by All-round and Coordinated Education. University of China, 15(12), 25-28.

Han, F.X., Zheng, J. (2015). Reform of Engineering Training Teaching Based on Engineering Education Certification. Experimental Technology and Management, 32(10), 178-181.

Han, F.X., Zheng, J. (2015). Reform of engineering training teaching based on the professional education of engineering education. Experimental Technology and Management, 32(10), 178-181.

Han, X.C., Yan, F., Wang, C.W. (2015). Exploration of excellent engineer talent training engineering education system. Journal of Experimental Technology and Management, 32(3), 13-17.

Kong, H.B., Ye, M., Wang, P.M. (2013). A Diversified History of Engineering Education. Higher Engineering Education Research, 30(8), 1-12.

Li, P.G., Xu, X.D., Chen, G.S. (2012). Analysis on Problems and Reasons of Practical Teaching in Undergraduate Engineering Education in China. Journal of Higher Engineering Education, 22(3), 1-6.

Li, Z., Xiang, C. (2016). Exploration and thinking of practice-driven engineering education curricula. Higher Engineering Education Research, 18(2), 74-79.

Lin, J. (2016). How to Understand and Solve Complex Engineering Problems - Based on the Definition and Requirements of "Washington Protocol". Higher Engineering Education Research, 4(5), 17-26.

Peng, Y.N., Lu, J.J., Zhou, Y.H. (2014). Study on training college students engineering thinking. Higher Engineering Education Research, 42(4), 1-5.

Walter, D., Wu, W.R., Wu, X.M. (2017). China's accession to the "Washington Agreement" under the background of innovative engineering personnel training exploration and practice. China Higher Education Research, 13(2), $82-85$.

Xie, Y.J. (2016). Changes in curriculum development of higher engineering education in China and curriculum management change. Higher Engineering Education Research, 16(3), 131-136.

Yu, S.W. (2013). Discussion on Some Problems of Modern Engineering Education. Higher Engineering Education Research, 41(2), 1-5. 
Zeng, D.W., Shen, J., Tao, X.H. (2013). Analysis of professional certification standards and concepts to enhance the quality of engineering education. Experimental Technology and Management, 30(12), 169-171.

Zhang, L.P., Kong, H.B., Chen, Z.C. (2012). International Progress in Engineering Master's Degree Education. Journal of Higher Engineering Education, 42(2), 21-28.

Zhou, H.F., Zhu, Z.W., Li, M.G. (2016). Development and Innovation of Engineering Education Certification and Its Enlightenment to Engineering Education in China - A Summary of 2016 International Conference on Engineering Education Certification. Journal of Chinese University, 40(1), 88-95.

Zhu, G.F. (2011). Several ideas in engineering education. Higher Engineering Education Research, 11(2), 1-5.

Zhu, G.F. (2015). Current Situation and Prospects of Engineering Education in China. Journal of Tsinghua University, 36(1), 13-20.

Zhu, G.F. (2016). The reform and development trend of China's engineering education. Higher Engineering Education Research, 34(5), 1-9. 